\title{
Role of internal variability of climate system in increase of air temperature in Wrocław (Poland) in the years 1951-2018
}

\section{Andrzej Antoni Marsz}

Polish Geophysical Society, Baltic Branch

\section{Anna Styszyńska}

Gdańsk University of Technology

Krystyna Bryś ( $\nabla$ krystyna.brys@upwr.edu.pl)

Wroclaw University of Environmental and Life Science; The Faculty of Environmental Engineering and Geodesy https://orcid.org/0000-0001-6970-9649

\section{Tadeusz Bryś}

Polish Geophysical Society, Wrocław Division

\section{Research Article}

Keywords: air temperature trend, macro-circulation conditions, sunshine duration, NAO, 39 radiative forcing, $\mathrm{CO} 2$

Posted Date: June 7th, 2021

DOl: https://doi.org/10.21203/rs.3.rs-491449/v1

License: (c) (1) This work is licensed under a Creative Commons Attribution 4.0 International License. Read Full License

Version of Record: A version of this preprint was published at Quaestiones Geographicae on September 1st, 2021. See the published version at https://doi.org/10.2478/quageo-2021-0027. 


\section{Role of internal variability of climate system in}

\section{2 increase of air temperature in Wrocław (Poland) in the}

\section{3 years 1951-2018}

5 Andrzej Antoni. Marsz ${ }^{1}$, Anna Styszyńska², Krystyna Bryśs ${ }^{3}$, Tadeusz Bryśs

$8 \quad{ }^{1}$ Polish Geophysical Society, Baltic Branch, Gdynia, Poland

$9 \quad{ }^{2}$ Department of Urban Design and Regional Planning, Faculty of Architecture, Gdańsk

10 University of Technology, Gdańsk, Poland

$11{ }^{3}$ Institute of Environmental Protection and Development, Faculty of Environmental Engineering

12 and Geodesy, Wroclaw University of Environmental and Life Science, Wrocław, Poland

$13{ }^{4}$ Polish Geophysical Society, Wrocław Division, Wrocław, Poland

16 * Corresponding author

17 E-mail: krystyna.brys@upwr.edu.pl

\section{Abstract:}

21 In the course of the annual air temperature in Wrocław (TWr variable) a rapid change of the

22 thermal regime was found between 1987 and 1989. A similar temperature change has occurred in 
23 Central Europe. TWr increased by more than 1 deg a strong, statistically significant positive trend

24 emerged. The analysis of processes showed that strong warming in the cold season of the year

25 (December-March) occurred as a result of an increase in the NAO intensity and warming in the

26 warm season as a result of increased sunshine duration. Multiple regression analysis has showed

27 that the winter NAO Hurrell's index explains $15 \%$ of TWr variance, and the sunshine duration of

28 the 'long day' (April-August) period 49\%, whereas radiative forcing 5.9\%. This indicates that

29 the factors incidental to the internal variability of the climate system explain $64 \%$ of the $\mathrm{TWr}$

30 variability and the effect of increased $\mathrm{CO}_{2}$ concentration only $\sim 6 \%$. The reason for this rapid

31 change of the thermal regime was a radical change in macro-circulation conditions in the

32 Atlantic-European circular sector, which took place between 1988 and 1989. It has similarly

33 changed the structure of the Central European weathers. The heat, which is the cause of warming

34 in Wrocław, comes from an increase in solar energy inflow (April-August) and also is

35 transported to Europe from the North Atlantic surface by atmospheric circulation (NAO). These

36 results indicate that the role of $\mathrm{CO}_{2}$ in shaping the contemporary temperature increase is

37 overestimated, whereas internal variability of the climate system is underestimated.

39 Key words: air temperature trend, macro-circulation conditions, sunshine duration, NAO, 40 radiative forcing, $\mathrm{CO}_{2}$

\section{Introduction and the research purpose}


46 (2001); Kożuchowski and Żmudzka, (2001); Philipona et al., (2009); Wójcik and Miętus, (2014);

47 BACC, (2008). The warmest region of Poland is Lower Silesia. This area is the south-western 48 part of Poland and borders the Federal Republic of Germany to the west, and the Czech Republic

49 to the south, from which it is separated by Sudetes - the mountain range with the elevation about

$50 \quad 1000-1600 \mathrm{~m}$ above sea level (Fig 1). Relatively high air temperature over the Lower Silesia area

51 is conditioned by an unrestricted inflow of air masses from the west and the occurrence of foehn

52 effects on the leeward slopes of Sudetes with air inflows from the southwest (Dubicka, 1994;

53 Dubicki et al., 2002; Kwiatkowski, 1975; Ojrzyńska, 2015; Ustrnul, 2006).

54 The capital of Lower Silesia is Wrocław, where a very rapid increase in air temperature is

55 observed. The increase in annual air temperature in Wrocław in the years 1951-2018 expressed

56 in degrees, calculated as the difference between the arithmetic means of the first five data (the

57 years 1951-1955) and the last five data (2014-2018) of this series, is $2.42^{\circ} \mathrm{C}$. The difference

58 between these averages is highly significant $(\mathrm{p}<0.001)$. The linear trend of the annual air

59 temperature in Wrocław in the years $1951-2018$ is equal to $+0.034( \pm 0.005)^{\circ} \mathrm{C} \cdot \mathrm{year}^{-1}$ and is

60 highly statistically significant $(\mathrm{p}<0.001)$. This trend is much stronger than the global trend in air

61 temperature $\left(+0.018^{\circ} \mathrm{C} \cdot\right.$ year $\left.^{-1}\right)$ or the northern hemisphere temperature trend $\left(+0.022^{\circ} \mathrm{C} \cdot \mathrm{year}^{-1}\right)$

62 between 1951 and 2017 as estimated by GISTEMP (ZonAnn. Ts. txt.; 2018). Temperature

63 changes in Wrocław in the years 1951-2018 are very strongly correlated with changes in annual

64 temperature at stations in Poland (correlation coefficients $r$ from 0.81 to 0.97 ) and at stations

65 located in Germany, Austria, the Czech Republic and Slovakia, less strongly but significantly

66 with air temperature at stations located in Denmark, southern Sweden, Lithuania, Belarus and

67 Ukraine. This proves that the temperature increase observed in Wrocław is not a local

68 phenomenon, but a manifestation of a process of supra-regional scale. 


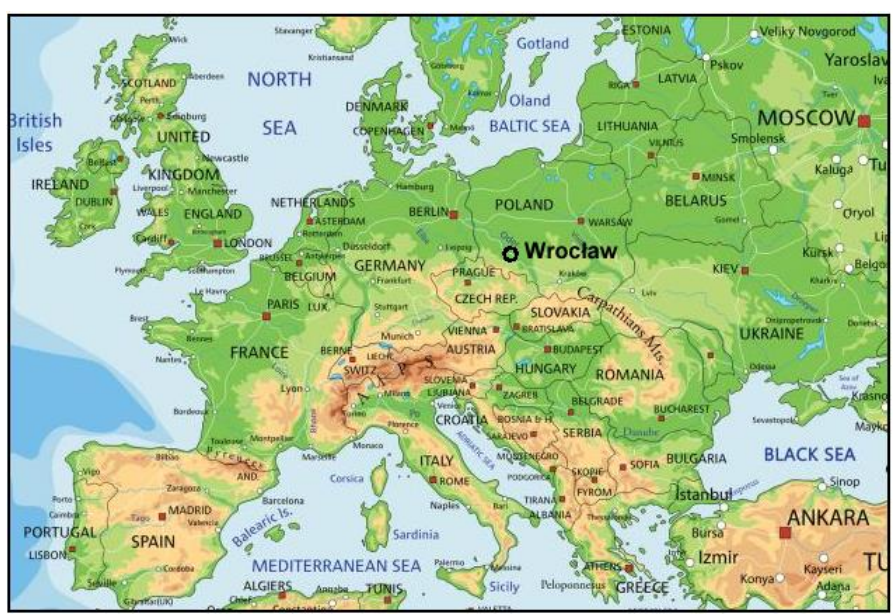

Fig 1. The geographical position of Wrocław in Europe

A strong rise in air temperature observed since the end of the 1980s is commonly explained

73 by the effects of the so-called 'Anthropogenic Global Warming' (AGW), which is in turn caused

74 by an increase in the concentration of greenhouse gases in the atmosphere. $\mathrm{CO}_{2}$ concentration in

75 the troposphere is particularly heavy and is undoubtedly an effect of human activity: the burning

76 of fossil fuels, both hard coal and brown coal, as well as hydrocarbons. The remaining causes of

77 this increase, such as deforestation, are also a result of human activity, although their role in

78 shaping the increase in greenhouse gas concentration in the atmosphere is less significant.

79 Meanwhile, the analysis of the temperature course in Wrocław indicates that changes in $\mathrm{CO}_{2}$

80 concentration in the atmosphere do not explain a number of aspects of its variability - both short-

81 and long-term, including discontinuity of this course and temperature increase much stronger

82 than global or hemispheric one.

83 The latest IPCC account (IPCC, 2014) in the Synthesis Report in Figure 1.9 (p. 48) shows the

84 contribution of individual components to the rise in air temperature in the years 1951-2010. The

85 total contribution of anthropogenic factors is estimated at $+0.7( \pm 0.1)^{\circ} \mathrm{C}$, while the contribution of

86 natural factors at $\pm 0.1^{\circ} \mathrm{C}$ and natural internal climate variability also at $\pm 0.1^{\circ} \mathrm{C}$. While the term 
87 'internal climate variability' is briefly explained in the 'Summary Report,' in order to understand 88 what the authors of the IPCC, (2014) meant by 'natural factors,' we need to go back to the 89 previous IPCC, (2007) where in the Technical Summary in Figure. TS.23 (p. 62), the authors 90 explain that the only natural factors considered are changes in solar activity and volcanic 91 eruptions. There is a very limited 'inventory' of natural factors that can influence variability and

92 climate change.

93 Therefore, the combined effect of 'natural factors' coming from outside the climate system 94 and climate variability as part of its internal dynamics, even if they were to operate in line with 95 each other, should affect air temperature variations no more than by $\pm 0.2^{\circ} \mathrm{C}$. The contribution of 96 natural intrinsic climate variability is assessed particularly modestly in the latest Report.

97 Paleoclimatic and paleoceanographic studies reveal that, in the relatively recent past, around 98 the last two thousand years, both global Earth's climate and the climate over particular areas have 99 shown long-term variability similar to that observed today in terms of its scale. These changes 100 occurred synchronously on the scale of the northern hemisphere, and not only in Europe and the 101 North Atlantic environment, as previously assumed (Mann, 2002; Oreopoulos et al., 2012). Quite 102 frequently, in dozens of paleoclimatic studies, there are successive periods of varied thermal 103 conditions in the northern hemisphere in the last 2000 years : 'the Roman Warm Period' (warm; 104 100 BCE to 200-300 CE), 'the Dark Ages - by Büntgen et al., (2016) is called as 'Later 105 Antique Little Ice Age' (chilly; 400-700 CE), 'the Mediaeval Warm Period' (warm; 900106 1200-1300 CE), a multi-phase period of progressive cooling called the Little Ice Age $(\sim 1500-$ $1071850 \mathrm{CE}$ ), with its thermal minimum in the second part of $18^{\text {th }}$ and the first decades of $19^{\text {th }}$ 108 centuries and the period of contemporary climate ( 1850 to the present day), occasionally named 109 'the Anthropocene period' or 'the industrial climate period'. For example, deep into Asia (Altai), 110 where all the above-mentioned climatic periods were documented, air temperature in the summer 
111 months during the Roman Warm Period (100 BCE -300 CE) was higher than nowadays

112 (Nazarov et al., 2016). In Alaska, in the sub-arctic zone, Hu et al., (2001) find the same periods in

113 the history of climate in the last twenty centuries, and state that both in the Roman Warm Period

114 and in the Medieval Warm Period, temperatures were higher or the same as today. The internal

115 variability of the Earth's climate system is responsible for all these changes, because then the

116 concentration of greenhouse gases, different than $\mathrm{H}_{2} \mathrm{O}$, in the atmosphere (with ca. 280 PPM for

$117 \mathrm{CO}_{2}$ ) was lesser than currently (with ca. $410 \mathrm{PPM}$ for $\mathrm{CO}_{2}$ ). Therefore, there are no compelling

118 reasons to believe that the above-mentioned variability merely stopped in the second half of the

119 20th and early 21st century and all, or almost all the observed changes in air temperature are

120 linked to increased concentration of greenhouse gases in the atmosphere, which in turn leads to

121 AGW.

122 Thereby, the showed premises direct an attempt to explain grounds of the air temperature

123 increase in Wrocław to the studying a role of internal dynamics of the climatic system, as a

124 reason of the observed air temperature changes.

125 The aim of this study is to assess the role of internal variability of the climate system in

126 shaping the variability of air temperature in Wrocław, a city with long-term meteorological

127 observations. Several weather stations, not too distant from one another, operating at the same

128 time in an area of little hypsometric differentiation (Dubicka and Pyka, 2001) have enabled

129 continuous record of changes in climatic elements after 1950. If we compare data from weather

130 stations in Wrocław, we can see that they are very strongly correlated. Accordingly, regardless of

131 inevitable minor differences resulting from the impact of the closest surroundings of these

132 stations, they provide a highly reliable record of changes in the climate of Wrocław occurring

133 from 1951 to the present day. Due to a strong increase in air temperature in recent years, it was

134 decided to go beyond the years 1951-2010 analysed in the IPCC, (2014) and cover the years 
$1351951-2018$ by the research in order to include the processes taking place presently in this 136 research.

137

\section{Source of the data and methods}

140 In the analyses carried out, time series of values of meteorological elements with monthly 141 resolution, characterizing climatic conditions of Wrocław, were used. The annual values are 142 calculated as simple arithmetic averages in a calendar year (January-December). The values of 143 monthly air temperature, monthly sums of precipitation, number of days with precipitation, 144 atmospheric pressure, relative humidity, general cloud cover come from official data collected by 145 the state observation network of the IMGW (Institute of Meteorology and Water Management) at 146 the meteorological station Wrocław (Czernecki et al., 2020). These series were taken from the 147 database: 'Meteorological data: Averages and monthly totals'; (version: 1.32, https:/meteomodel.

148 pl. data/monthly average/). The meteorological station of the IMGW Wrocław (airport station:

149 Wrocław-Strachowice located in a west district of the city), from which a series of monthly air 150 temperatures were collected, is outside the range of the urban heat island (Szymanowski, 2005, 151 2004).

152 The long (the years 1791-2007) annual temperature series used comes from Bryś and Bryś, 153 (2010). It was supplemented by official data from the IMGW observation network until 2018. 154 The monthly sunshine values for the years 1951-1960 come from the Meteorological 155 Observatory of the Wrocław University located in Wrocław-Biskupin (east district of the city), 156 for 1961-2018 from the Meteorological Observatory of the Wrocław University of Life 157 Sciences located in Wrocław-Swojec (east district of the city) (Bryś et al., 2019). The 
158 twostations are separated in a straight line by a distance of about $5 \mathrm{~km}$. The series used in this wo

159 rk isa sequence connected from both these stations. Before the combination these values were 160 examined in detail for their homogeneity, the result was positive.

161 An increase of the $\mathrm{CO}_{2}$ concentration in the atmosphere gives an additional flux of energy 162 directed to the Earth's surface, which causes a rise in temperature. The IPCC $(2014,2007,2001)$ 163 refer to this stream as 'radiative forcing'. The radiative forcing values (hereinafter referred to as 164 variable $\Delta \mathrm{F} ; \mathrm{W} \cdot \mathrm{m}^{-2}$ ) were calculated from the series of annual concentrations of $\mathrm{CO}_{2}$ in the 165 atmosphere using the formula (after IPCC, (2001), chapter 6, tab. 6.2).

$$
\Delta \mathrm{F}=5.35 \cdot \ln \left(\mathrm{C} / \mathrm{C}_{0}\right)
$$

167 where:

$168 \Delta \mathrm{F}$ - radiative forcing $\left(\mathrm{W} \cdot \mathrm{m}^{-2}\right)$,

$169 \mathrm{C}$ - current concentration of $\mathrm{CO}_{2}$ in the atmosphere (PPM),

$170 \mathrm{C}_{0}$ - concentration of $\mathrm{CO}_{2}$ in the pre-industrial era (280 PPM),

171 ln - natural logarithm.

172 The series values of the average annual $\mathrm{CO}_{2}$ concentration from which $\Delta \mathrm{F}$ was calculated for 173 the years 1951-1958 are taken from the Global Mean Mixing Ratios: NASA GISS Data 174 (https://data. giss. nasa. gov/modelforce/ghgases/; Fig1A. ext. txt) and for the years 1959-2018 175 from the Mauna Loa $\mathrm{CO}_{2}$ annual mean data: NOAA Earth System Research Laboratory, Global 176 Monitoring Division (ftp://aftp. cmdl. noaa. gov/; products/trends/co2_anmean_mlo. txt).

177 The calendar of frequency of the middle-tropospheric circulation types (500 hPa) according 178 to the Wangengeim-Girs classification (Girs, 1971; Girs and Kondratovich, 1978) comes for the 179 years 1951-2018 from AARI (Arctic and Antarctic Research Institute, Russian Federation, St. 180 Petersburg). These data for 1951-2005 were taken from Annex 1 of the work of Dimitrieev and 181 Belyazo, (2006), whereas the unpublished data for the remaining years were obtained directly 
182 from AARI. Illustrations showing patterns of long-wave distribution in the $\mathrm{W}, \mathrm{E}$ and $\mathrm{C}$

183 circulation types are not presented in this work, they are among others published in Barry and

184 Carleton, (2013) as Fig. 7.9 (p. 569). A series of the NAO (Hurrell, 1995) winter (DJFM) station

185 indicators (collection: DJFM North Atlantic Oscillation Index Station-Based) was downloaded 186 from the NCAR UCAR Climate Data Guide

187 (https://climatedataguide.ucar.edu/sites/default/files/nao_station_djfm.txt).

188 The analysis methods used are standard statistical methods - correlation analysis, regression 189 analysis and variance analysis. Statistical significance of correlation coefficients and estimated 190 regression coefficients was determined by the Student's $t$ test, statistical significance of 191 regressionequations by the Fischer-Snedecor's F test. This paper does not discuss the factors 192 influencing changes in air temperature, which are referred to in the (IPCC, 2014) as 'natural 193 factors', i. e. the variable solar activity and volcanism. These come from outside the climate 194 system and their activity can only modulate the variable waveforms courses of TWr (Fig 2) 195 generated by the climate system. However, they were considered in the analyses, but their 196 contribution to the creation of TWr variability in the considered period is negligible, because the

197 TSI (total solar irradiation) contribution is $\sim 1 \%$, and the contribution of stratospheric volcanic 198 aerosols is practically zero. The data sets used for these estimates were TSI Reconstruction based 199 on NRLTSI2 (https://spot.colorado.edu/ koppg/TSI/Historical_TSI_Reconstruction.txt) and the

200 NASA GISS stratospherical aerosol optical depth at $550 \mathrm{~nm}$

201 (https://climexp.knmi.nl/data/isaod_gl.dat). 
203 Course of annual air temperature in Wrocław in the

204 years 1951-2018 against this course from the last

205 decade of $18^{\text {th }}$ century

207 The course of air temperature in the years 1791-2018

209 Wrocław has a relatively long series of instrumental measurements of air temperature

210 compared to other places in Europe. Temperature recording started in 1791 and has continued at

211 several points within the city area. Individual sections of the measurement series were checked

212 and homogenized Bryś and Bryś, (2010), creating a uniform sequence covering the years 1791-

213 2007. This allows us to compare the course of the temperature curve in the years 1951-2018

214 (processed period) to the changes occurring in a much longer period. The analysis is based on the

215 annual average air temperature - a comprehensive measure of thermal changes occurring in

216 Wrocław.

217 Figure 2 shows the course of annual temperature changes in Wrocław in the years 1791-

218 2018, presenting the values of annual temperature as deviations from the long-term average. The

219 average annual temperature in this period is $8.68^{\circ} \mathrm{C}$, its standard deviation (SD) being $1.05^{\circ} \mathrm{C}$. 


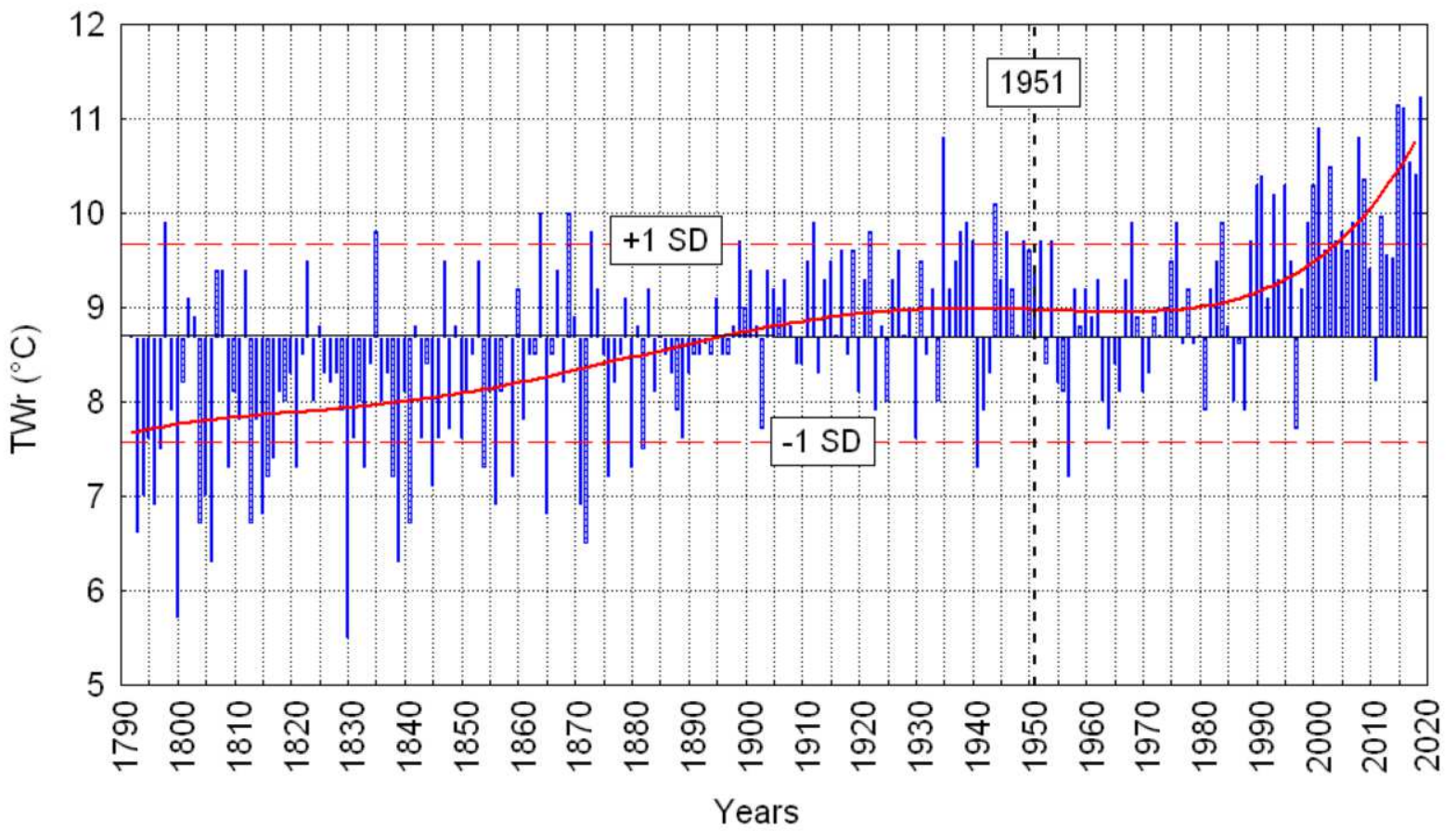

223 Fig 2. The course of the annual air temperature in Wrocław in the years 1791-2018 as a deviation from

224 the long-term average. Continuous curve - adjustment of the polynomial to the power of 5 to the empirical 225 courses. The year 1951 (vertical dotted line) is marked, the initial year of the period 1951-2018 analysed 226 in detail. Horizontal dashed lines mark limits of the \pm 1 standard deviation (SD)

The course of annual temperature in Wrocław reveals the occurrence of long-term, multi229 decadal variability of considerable amplitude (min. $5.5^{\circ} \mathrm{C}$ in 1829 , max. $11.2^{\circ} \mathrm{C}$ in 2018 ), which 230 manifests itself as successive periods of cooling and warming. The changes take place against the 231 background of a long-term (in fact on a centennial timescale) positive trend in a series of annual 232 temperatures. The rate of temperature rise varies, and is a function of time, and thus the actual 233 trend is non-linear in its nature. The highest rate of temperature increase occurs at the end of the 234 course, approximately since the turn of the 1980s and 1990s (Fig 2). The linear trend, calculated 235 for the years $1791-2018$, has a value equal to $+0.0093( \pm 0.0009)^{\circ} \mathrm{C} \cdot$ years $^{-1}$ and explains for (adj. 
$236 \mathrm{R}^{2}$ ) around $34 \%$ of variance in the annual temperature in these 228 years. As a result of the 237 positive trend in the series of annual temperatures in Wrocław in the 1890s, the annual 238 temperature relatively permanently assumed higher values than the long-term average (Fig 2), 239 and since the beginning of the 1990s, on average, it has remained at the level higher by $+1 \mathrm{SD}$ 240 than the multi-annual average.

242 The course of annual air temperature in the years 1951-2018 and its

243 peculiarity

245 The period of 1951-2018, for which the analysis of the role of variability within the system 246 in the shaping of temperature changes is made, is in the final part of the 228 -year series and 247 constitutes its warmest fragment. There is a strong $\left(+0.034( \pm 0.005)^{\circ} \mathrm{C}\right)$ and highly significant $(\mathrm{p}$ $248<0.001)$ positive trend of the annual air temperature in Wrocław calculated for these 68 years, 249 what earlier (Section 1) it has only briefly presented about.

250 The survey of annual air temperature in Wrocław (hereinafter TWr variable) supported by 251 an analysis of the envelope of its variability band indicates that it is divided into two parts (Fig 3).

252 The boundary between two different periods in the course of temperature curve occurs between 2531987 and 1989, when there is a rapid increase in annual temperature and a remarkable shift in the 254 nature of its course. 1988 is taken as the boundary year between the two periods. 


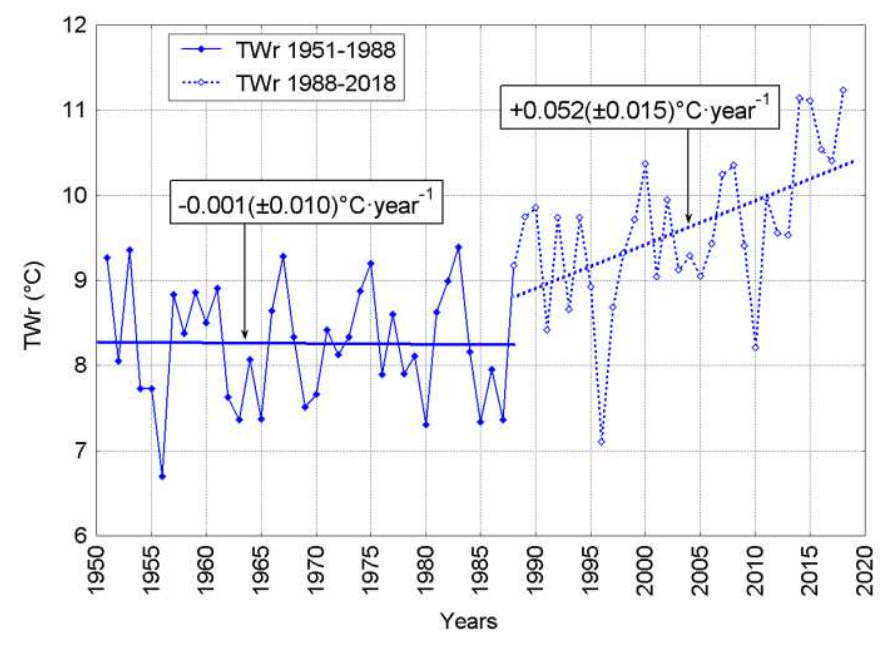

258 Fig 3. The course of the annual air temperature in Wrocław (TWr) in the years 1951-2018. 259 Significantly different courses in the periods 1951-1988 and 1988-2018 can be seen. Marked 260 trends and their values in both periods

In the first period (1951-1988), differences between particular years are significant, the 263 average temperature is lower than the multiannual average of $1791-2018\left(+8.26^{\circ} \mathrm{C}\right)$, and the 264 trend in the series is zero. In the second period $(1988-2018)$, a strong $\left(+0.052( \pm 0.015)^{\circ} \mathrm{C} \cdot \mathrm{year}^{-1}\right)$ 265 and statistically significant $(\mathrm{p}=0.002)$ positive trend appears in $\mathrm{TWr}$, and the range of inter266 annual variability is changing rapidly. The differences between successive years are then 267 decreasing and at the same time the following years are getting warmer. The thermal regime 268 change occurred suddenly, in 2-3 years, and has a radical character (Fig 3) as a rapidly transition, 269 transferring the further course of TWr to a new initial level, more than 1 degree higher than the 270 previous level. The changes in the annual temperature value and the range of variation between 271 these periods are so large that TWr forms separate populations in the both periods (Fig 4). 


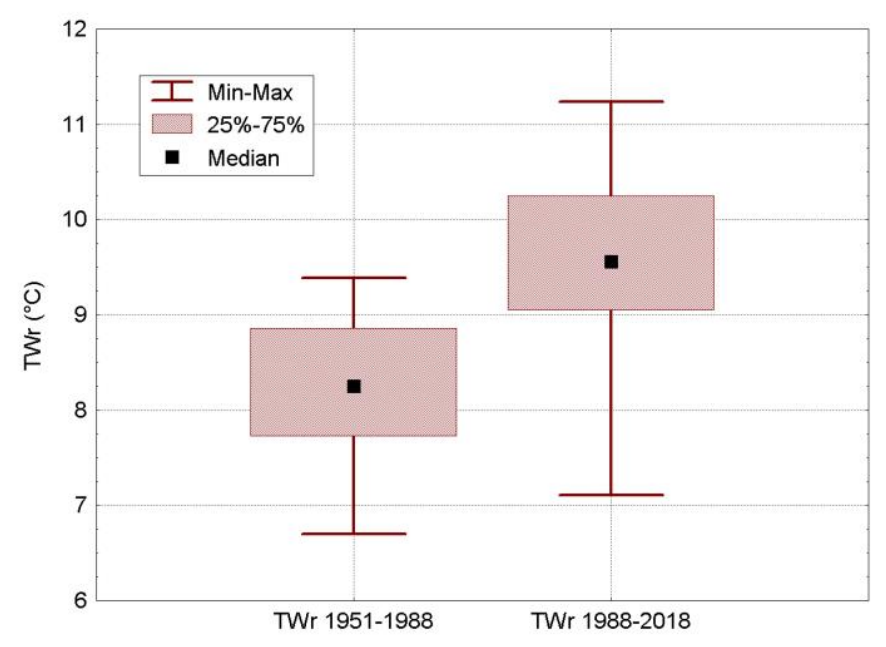

275 Fig 4. Variation ranges of the annual air temperature in Wrocław (TWr) in the both periods: 19512761988 and 1988-2018. It appears noteworthy that in the second period, the lower limit of the second 277 quartile is higher than the upper limit of the third quartile in the previous period, and the median in the 278 second period is above the absolute maximum in the first period

Such course of the TWr values explains, that a rapid temperature increase began after 1988, 281 and the whole temperature increase in the considered period 1951-2018 occurred in its second 282 part, that is between 1988 and 2018. This course differs considerably from the monotonically 283 increasing course of $\mathrm{CO}_{2}$ concentration in the atmosphere (Fig 5).

284 This course of the TWr value explains that the rapid increase in temperature began after 2851988 , and the entire increase in temperature in the considered period of 1951-2018 occurred only 286 in its second part, in 1988-2018, while the uniform linear trend TWr calculated for the period 287 1951-2018 does not reflect the actual course of changes TWr. 


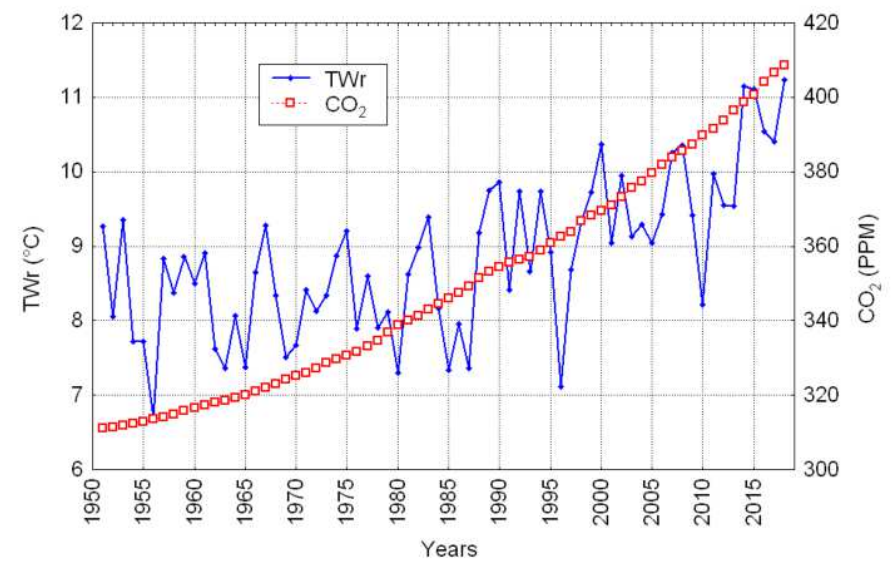

290 Fig 5. The courses of the annual air temperature in Wrocław (TWr) and the average annual

291 values of $\mathrm{CO}_{2}$ concentration in the atmosphere

293 The trends in the course of $\mathrm{TWr}$ and $\mathrm{CO}_{2}$ concentration coincide only after 1988; earlier on,

294 increasing $\mathrm{CO}_{2}$ concentration is not reflected in the long-term (38 years) course of temperature.

295 Moreover, the short-term variability of both courses (Fig 5) shows that the monotonous increase

296 in $\mathrm{CO}_{2}$ concentration does not seem to be connected with the strong variability of TWr over the

297 years. It follows that the reasons for the sudden change in the TWr regime after 1988 are also to

298 be sought in the processes related to the internal dynamics of the climate system rather than in the

299 processes associated with AGW.

300

\section{The factors affecting annual air temperature increase}

\section{2 in Wrocław}

304 If we consider possible reasons for the increase in the annual temperature in Wrocław after

3051988 from a purely thermodynamic point of view, a sensible conclusion is that the amount of heat 
must have increased in the atmosphere during the period in question. In addition, the increase in

307 the amount of heat in the atmosphere must have occurred rapidly, in a relatively short time,

308 within two or three years; and then it has been increasing progressively.

309 In general, an increase in the amount of heat over a research area can occur due to two factors:

310 1) by a more frequent advection of air masses with increasing enthalpy as a consequence of

311 atmospheric circulation influence (advection factor) or/and 2) by changes in the net radiation of

312 this area towards its growth (radiation factor). In the last case an increase of the heat resources

313 may occur when the amount of solar energy reaching the ground increases, or when heat loss

314 from the atmosphere is reduced. The growth of radiation inflow to the ground may occur due to a

315 limitation of the cloudiness and an increase of the sunshine duration, as well as an increase of the

316 atmospheric transparency and/or an increase of the solar constant.

317 The changes in the solar constant which is a conventional measure of mean TSI (Total Solar

318 Irradiance), i.e. solar energy reaching the upper boundary of the atmosphere, as a basic reason for

319 air temperature increase after 1988 can be ignored. Differences in an amount of the solar

320 constant, being a result of the variable solar activity are virtually insignificant, because reach only

$3211,7 \mathrm{~W} \cdot \mathrm{m}^{-2}$ (in the year 1680 , when was the Maunder's Minimum $-1360.0 \mathrm{~W} \cdot \mathrm{m}^{-2}$ and maximum

322 in the year $2002-1361.7 \mathrm{~W} \cdot \mathrm{m}^{-2}$, at the mean value $-1360.45 \mathrm{~W} \cdot \mathrm{m}^{-2}$; Kopp et al., (2016). In the

323 examined period 1951-2018, they are on average lesser from $1 \mathrm{~W} \cdot \mathrm{m}^{-2}$, moreover the course of

324 TSI variability doesn't enable to be a reliable basis to their connections with the observed rapid

325 increase of $\mathrm{TWr}$ after 1988. The changes in the stratospheric aerosol concentration (GISS

326 stratospheric aerosol optical depth at $550 \mathrm{~nm}$ ) also don't show any significant connections with

327 the course of $\operatorname{TWr}(\mathrm{r}=-0.15, \mathrm{p}=0.231)$.

328 Limitation of heat loss may take place as a result of chemical changes in the atmosphere: an 329 increase in the content of greenhouse gases in the atmosphere $\left(\right.$ mostly $\left.\mathrm{CO}_{2}\right)$ or an increase in 
330 cloud cover during the cold season of the year. In both cases, return radiation increases.

331 Reduction of heat loss by increasing greenhouse gas concentration, mostly $\mathrm{CO}_{2}$, and hence a rise

332 in annual temperature is nothing other than AGW. In this case, human activity is the cause of the

333 change in the heat balance; this change is not brought about by any processes of changeability

334 within the system. This indicates that despite the unsatisfactory explanation of the changes in

335 TWr by the changes in $\mathrm{CO}_{2}$ concentration, the radiatiative forcing $(\Delta \mathrm{F})$ cannot be ignored in

336 further considerations and estimates.

337 Studies into the factors resulting from the internal variability of the climate system in shaping

338 variability of the annual air temperature require identification and selection of variables most

339 strongly influencing the deviation in the annual temperature value from its idealised annual cycle

340 resulting from the inflow of solar energy and heat brought in by advection.

\section{The radiation factor activity}

344 At a point with given geographical coordinates, potential solar energy inflow is the same on

345 successive days in the year. A potential source of solar energy is defined as the amount of solar

346 energy penetrating the atmosphere at its upper boundary a given day. It is a function of the

347 astronomical factors (length of a day, the Sun's height, which in turn are a function of the Sun's

348 declination and the latitude) and TSI (Total Solar Irradiance) values. Thus, both monthly and

349 annual values of the potential solar radiation inflow, being daily totals in a given month or year,

350 cannot differ from each other in successive years. Therefore, if the annual average temperature

351 involves variation within the year, this variation, if caused by changes in the amount of solar

352 energy supplied, with a relatively constant TSI values, must be brought about primarily by factors 
353 that interfere with the flow of solar energy to the Earth's surface at given geographical 354 coordinates.

355 The basic factor regulating the flow of solar energy to the Earth's surface is cloudiness.

356 Clouds are shaped by changing weather conditions or, alternatively, by the variability of synoptic

357 situations. Internal processes of the climate system are manifested through this type of variability.

358 Cloudiness is observed as general cloud cover $(\mathrm{N})$, both during the day and night, and then

359 averaged to daily, monthly and eventually to annual values. Solar energy flows to the Earth's

360 surface only during the day. For this reason, data on cloud cover do not provide fully reliable

361 information about the amount of solar energy flowing to the Earth's surface. Correlation of

362 monthly and annual values of general cloudiness in Wrocław with the same series of air

363 temperature shows that such relation changes the sign into negative or positive during the year,

364 and statistically significant correlations occur only in some months of the warm season (Table 1).

365 Statistically significant relationships between annual cloudiness and annual temperature are

366 missing.

368 Table 1. Values of correlation coefficients ( $r$ ) between monthly and annual cloudiness in

369 Wrocław and air temperature in Wrocław, and their statistical significance (p). Significant

370 correlations $(\mathrm{p}<0.05)$ are in bold type. The values of $\mathrm{p}$ described as 0.000 mean that $\mathrm{p}<<0.001$.

371 Analysis period: 1951-2018.

\begin{tabular}{|c|c|c|c|c|c|c|c|c|c|c|c|c|c|}
\hline & Jan & Feb & Mar & Apr & May & Jun & Jul & Aug & Sep & Oct & Nov & Dec & Year \\
\hline $\mathrm{r}$ & 0.10 & 0.21 & -0.18 & $\mathbf{- 0 . 3 4}$ & $\mathbf{- 0 . 3 8}$ & $\mathbf{- 0 . 3 3}$ & $\mathbf{- 0 . 5 2}$ & -0.24 & $\mathbf{- 0 . 4 5}$ & 0.01 & 0.09 & 0.13 & 0.12 \\
\hline $\mathrm{p}$ & 0.401 & 0.092 & 0.152 & 0.004 & 0.001 & 0.006 & 0.000 & 0.053 & 0.000 & 0.929 & 0.477 & 0.280 & 0.344 \\
\hline
\end{tabular}


373 Sunshine duration is a climatic element that informs us about the time of solar operation 374 during a day, month or year. It takes into account the 'disturbing' effect of cloud cover, but it 375 does not inform us about the amount of energy coming in, but only about the time span the 376 energy was coming in. Statistically, it can be assumed that the amount of solar radiation flowing 377 to the Earth's surface averaged in monthly or longer periods is related to the sunshine duration, 378 because when the greater the amount of sunshine duration, the more solar energy comes to the 379 ground. This relationship is described by the Angström-Prescott equation, then transformed into 380 simpler form by Black et al., (1954) which allows to estimate with high accuracy the total 381 radiation from the sunshine duration values. This equation is commonly used to estimate the 382 amount of energy flowing to the Earth's surface from the sunshine (Besharat et al., 2013). The 383 application of this equation has shown that in the area of Lower Silesia there are very strong and 384 highly significant relationships between the amount of sunshine duration and the amount of solar 385 energy flowing to the ground (Bryś et al., 2020; Urban et al., 2018). The described relations cause 386 that in Wrocław there are strong and highly significant directly connections between sunshine 387 duration and air temperature. The analysis of relations between monthly sunshine and monthly air 388 temperature in Wrocław gives the results summarized in Table 2.

390 Table 2. Values of correlation coefficients (r) between monthly and annual sunshine, and monthly 391 and annual air temperature in Wrocław (1951-2018) along with their statistical significance (p). 392 Symbols as in Tab. 1.

\begin{tabular}{|c|c|c|c|c|c|c|c|c|c|c|c|c|c|}
\hline & Jan & Feb & Mar & Apr & May & Jun & Jul & Aug & Sep & Oct & Nov & Dec & Year \\
\hline r & 0,07 & $-0,11$ & $\mathbf{0 , 2 7}$ & $\mathbf{0 , 6 4}$ & $\mathbf{0 , 6 2}$ & $\mathbf{0 , 6 6}$ & $\mathbf{0 , 8 1}$ & $\mathbf{0 , 7 4}$ & $\mathbf{0 , 6 1}$ & 0,14 & 0,02 & 0,14 & $\mathbf{0 , 6 1}$ \\
\hline $\mathrm{p}$ & 0.583 & 0.381 & 0.025 & 0.000 & 0.000 & 0.000 & 0.000 & 0.000 & 0.000 & 0.248 & 0.847 & 0.239 & 0.000 \\
\hline
\end{tabular}


394 The distribution of the values of correlation coefficients indicates that in the period from

395 March to September inclusive, sunshine and air temperature correlations in Wrocław are

396 significant, while the correlations in the period from April to September are highly significant.

397 Accordingly, the annual air temperature is also quite strongly and significantly associated with 398 annual sunshine duration, and its variability is explained by approximately $37 \%$ of TWr variance.

399 The largest amount of solar energy is supplied during the 'long-day' months. This period can

400 be defined as the period in which the length of the day during the whole month is greater than 12

401 hours. This means that the 'long-day' period stretches from April to August inclusive. The

402 variability of sunshine during the 'long-day' months explains for $\sim 81 \%$ of the annual sunshine

403 variance $(\mathrm{R}=0.90)$ and about $48 \%$ of the annual temperature variance in Wrocław. 'Long-day'

404 sunshine $\left(\mathrm{ShWr}_{04-08}\right)$ in Wrocław is clearly more strongly correlated with the annual temperature

$405(\mathrm{r}=0.70)$ than with the annual sunshine duration (Tab 2).

406 A review of scatterplots and courses (Fig 6) of the annual air temperature in Wrocław as a

407 linear function of $\mathrm{ShWr}_{04-08}$ reveals that the most important features of temperature changes, such

408 as a rapid change of the temperature from one variability regime to another and a positive trend

409 after 1988, are quite well represented. This proves that $\mathrm{ShWr}_{04-08}$ variability is one of the causes

410 of TWr variability. At the same time, it can be observed that in some years, there are significant

411 differences between the observed $\mathrm{TWr}$ values and the $\mathrm{TWr}$ values estimated from the

412 dependencies, indicating that other factors than $\mathrm{ShWr}_{04-08}$ need to be considered, which shape the 413 variability of TWr. 


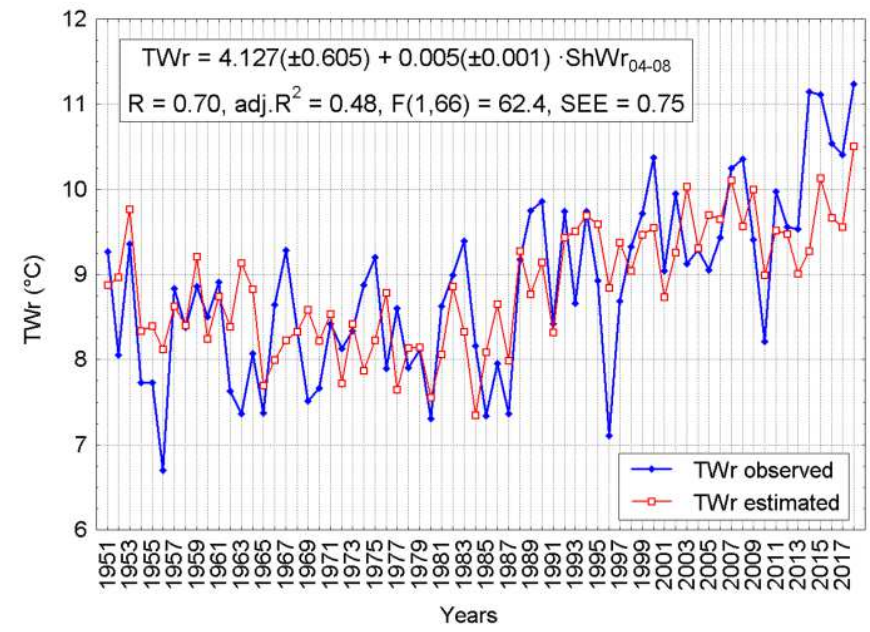

416 Fig 6. The course of annual air temperature in Wrocław (TWr) and annual air temperature estimated based

417 on 'long-day' months of sunshine duration values $\left(\mathrm{ShWr}_{04-08}\right)$ in Wrocław. The relationship between $\mathrm{TWr}$

418 and $\mathrm{ShWr}_{04-08}$ and its statistical characteristics are in an upper frame of the figure estimated from $\mathrm{ShWr}_{04-08}$ are particularly large when the average temperature of the first quarter in Wrocław is either significantly lower than the average (e.g. 1956, 1963, 1969, 1996, ... ), or

423 much higher than the average (e.g. 1974, 1975, 1989, 1990, ... ). This indicates that possibly the

424 most important yet ignored factor is one that regulates thermal relations in the cold season of the 425 year. 
432 NAO essentially regulates winter temperature over large areas of Europe and Poland (Hurrell,

433 1995; Hurrell et al., 2008; Marsz and Styszyńska, 2010; van Loon and Rogers, 1978).

$434 \quad \mathrm{NAO}$ is the result of climate variability within the system, and results from the interaction of

435 the ocean and atmosphere over the North Atlantic (Curry and McCartney, 2001; Czaja et al., 436 2003; Czaja and Frankignoul, 2002; Frankignoul et al., 2001). A number of studies (e.g. Cohen

437 and Barlow, (2005); Semenov et al., (2008) have shown that there are no causal relationships

438 between increasing $\mathrm{CO}_{2}$ concentration in the atmosphere or AGW in general and NAO 439 variability.

440 In winter periods (December-March), when NAO reaches the highest intensity. In the 441 positive phase of oscillation, maritime Polar air mass 'heated' over the Atlantic comes over 442 Poland; it is transformed to the degree approximately inversely proportional to the value of the 443 Hurrell's winter NAO index (Hurrell, 1995). Due to advection of warm maritime air, the winter 444 temperature is higher than the climate norm, especially high when the Hurrell's NAO index 445 reaches values greater than +1.0 . As a result, in case of a series of consecutive years in which 446 NAO is in the positive phase and the value of winter NAO index reaches higher values, a fast and 447 relatively strong upward trend of air temperature is observed.

448 In the negative phase of $\mathrm{NAO}$, southern circulation dominates and the relations of air 449 temperature with the NAO index value become non-stationary, due to the possibility of advection 450 from both the northern and eastern sector as well as the southern sector. However, 'cold' 451 advections are more frequent, which means that in the negative phases of NAO, cold winters in 452 Poland prevail (Marsz, 2006). With NAO values lower than -2.0, winters in Poland are usually 453 much cooler than their climate norm. A series of years with negative NAO values results in a 454 negative trend of air temperature and/ or a cooling period. 
456 relations with monthly air temperature in Wrocław. The results of the analysis are presented in 457 Table 3.

Table 3 Values of correlation coefficients (r) and their statistical significance (p) between (DJFM)

460 Hurrell's winter NAO index and monthly and annual air temperature in Wrocław (1951-2018). Symbols 461 as in Tab. 1.

462

\begin{tabular}{|c|c|c|c|c|c|c|c|c|c|c|c|c|c|}
\hline Month & Jan & Feb & Mar & Apr & May & Jun & Jul & Aug & Sep & Oct & Nov & Dec & Year \\
\hline $\mathrm{r}$ & $\mathbf{0 , 5 7}$ & $\mathbf{0 , 4 6}$ & $\mathbf{0 , 6 1}$ & 0,19 & 0,19 & 0,02 & 0,21 & $\mathbf{0 , 3 2}$ & 0,23 & 0,14 & $-0,16$ & 0,24 & $\mathbf{0 , 5 8}$ \\
\hline $\mathrm{p}$ & 0,000 & 0,000 & 0,000 & 0,114 & 0,125 & 0,895 & 0,080 & 0,008 & 0,058 & 0,258 & 0,198 & 0,052 & 0,000 \\
\hline
\end{tabular}

469 insignificant. Such correlation of the winter NAO index with monthly temperature, distributed 470 over time, including asynchronous August correlation, is typical for the whole of Poland (Marsz 471 and Styszyńska, 2010).

472 The range of seasonal variations in air temperature is the largest during winter. For this 473 reason, the variability of air temperature of the first quarter (January-March) explains $474\left(\operatorname{adj} . \mathrm{R}^{2} \cdot 100 \%\right) 57,5 \%$ the variance of annual temperature in Wrocław in the years 1951-2018. 475 The reliable explanation of monthly temperature variability in Wrocław in the first quarter by the 
476 winter NAO index (about 50\%) is the most important reason for the strong and highly significant 477 correlation of the winter NAO Hurrell's index also with TWr.

\section{The analysis and its results}

Thus, the two variables can be used to determine the role of factors operating within the system in shaping the variability of annual temperature in Wrocław: sunshine duration in the

483 'long-day' months in Wrocław $\mathrm{ShWr}_{04-08}$ and the Hurrell's winter NAO index (1995) - NAOH

484 variable. These are not all possible variables, however, these are possibly the most important 485 ones.

486 Multiple regression was used to analyse the relationships between the variables, in which the 487 explained variable was the annual temperature in Wrocław (TWr) and the explanatory variable 488 (independent) was sunshine duration in the 'long-day' months $\left(\mathrm{ShWr}_{04-08}\right)$ and the station-based 489 Hurrell's North Atlantic Oscillation Index $\left(\mathrm{NAO}_{\mathrm{H}}\right)$. The estimation of the parameters of the 490 multiple regression equation using the least squares method produced the following result:

$$
\mathrm{TWr}=4.8966( \pm 0.5305)+0.0039( \pm 0.0005) \cdot \mathrm{ShWr}_{04-08}+0.1937( \pm 0.0367) \cdot \mathrm{NAO}_{\mathrm{H}} \quad[2]
$$

494 There is the statistical characteristics of the equation: $\mathrm{R}$ (multiple regression correlation 495 coefficient $)=0.80$, adj. $\mathrm{R}^{2}$ (corrected for the number of degrees of freedom, the coefficient of 496 determination $)=0.6290, \mathrm{~F}(2.65)=57.8$ (Fisher-Snedecor test $), \mathrm{p}$ (significance of the equation) $497<<0.001$, SEE (standard error of estimation) $=0.63$. The estimation of intercept and regression 
498 coefficients is highly statistically significant $(\mathrm{p}<<0.001)$. The distribution of residuals is normal,

499 and the residuals and deleted residuals are closely related linearly.

500 In the equation [2], the variability $\mathrm{ShWr}_{04-08}$ explains for $48.6 \%$ and the variability $\mathrm{NAO}_{\mathrm{H}}$ for

$501 \quad 15.4 \%$ of the annual variance of air temperature in Wrocław in the years 1951-2018. The

502 scatterplot of the values estimated using this equation [2] in relation to the observed values is

503 presented in Fig. 7, and the courses of the observed and calculated TWr values (using the

504 equation [2]) is shown in Fig. 8.

505 In the course of the TWr values, estimated with equation [2], a few cases of strong

506 underestimation of annual temperature value (e.g. in 2013) can be noted. The residual analysis

507 showed that these are the cases in which, with a negative NAO value in the cold period,

508 advection of warm air from the south predominated.

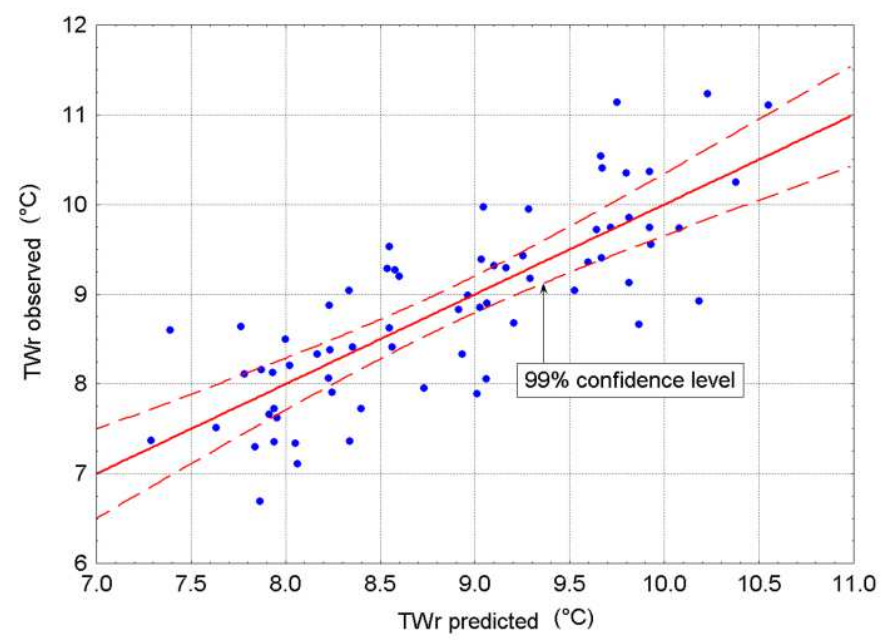

509

510

511 Fig 7. The predicted (from equation [2]) values of annual air temperature in Wrockaw (TWr) in relation to

512 the observed values. The dotted line indicates 99\% confidence interval (1951-2018) 


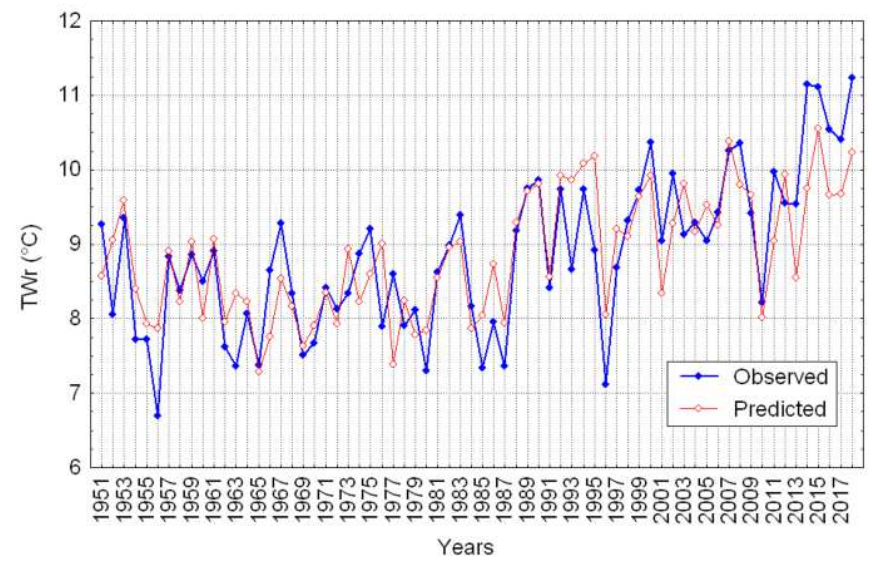

516 Fig 8. The courses of the observed and predicted (from equation [2]) values of annual air temperature in

517 Wrocław (TWr) in 1951-2018

520 A weak, statistically insignificant trend is observed in the remainder of equation [2], and the 521 whole series of residuals is quite strongly $(\mathrm{r}=0.53)$ correlated with the temperature of the fourth 522 quarter (October-December) in Wrocław. This indicates that equation [2] does not include an 523 increase in air temperature occurring in this part of the year. Considering the selection of 524 explanatory variables, it is understandable. After introducing the NAO station-based index from 525 December as the third variable in the equation, the equation remains highly significant, but the 526 degree of explanation of the dependent variable increases so slightly (by $2 \%$ ) that it does not 527 justify its further complication.

528 The estimated TWr trend in the series of values calculated from equation [2] is equal to $529+0.025( \pm 0.004)^{\circ} \mathrm{C}$. It is a trend of $0.009^{\circ} \mathrm{C} \cdot$ year $^{-1}$, and it is lower than the trend occurring in the 530 observed series of annual air temperature in Wrocław in the period in question $531\left(+0.034( \pm 0.005)^{\circ} \mathrm{C} \cdot\right.$ year $\left.^{-1}\right)$. Considering the errors in estimating both trends, the difference is 532 statistically insignificant. It can be assumed, however, that the reduced value of the annual 
533 temperature trend in Wrocław results from ignoring the influence of $\mathrm{CO}_{2}$ concentration increase

534 in the atmosphere, giving an additional energy stream directed to the Earth's surface, which is the

535 cause of temperature growth, that is 'radiative forcing' ( $\Delta \mathrm{F}$ variable, see equation [1]).

536 The calculated values of radiative forcing according to formula [1] for the years 1951-2018

537 were introduced as the third variable into equation [2] and the parameters of this equation 538 (equation [3]) and its statistical characteristics were calculated. The obtained results are as 539 follows:

$541 \mathrm{TWr}=5.396( \pm 0.509)+0.003( \pm 0.001) \cdot \mathrm{ShWr}_{04-08}+0.178( \pm 0.034) \cdot \mathrm{NAO}_{\mathrm{H}}+0.756( \pm 0.214) \cdot \Delta \mathrm{F}[3]$

543 Equation [3] is highly significant: $(\mathrm{F}(3.64)=49.5, \mathrm{p}<<0.001)$, all its parameters (constant 544 term, regression coefficients) are also estimated with high significance ( $\mathrm{p}<0.001$; $\mathrm{t}$-test). The 545 multiple correlation coefficient slightly increased in relation to equation [1], namely by 0.036 ( $R$ $546=0.836)$; the determination coefficient increased a little more. $\left(\operatorname{adj} . \mathrm{R}^{2}=0.685\right)$. The standard 547 error of estimation of the TWr value decreased slightly ( $\mathrm{SEE}=0.58)$.

548 From the analysis of variance, it follows that, in the equation [3], variability $\mathrm{ShWr}_{04-08}$ 549 explains for $49 \%$, variability $\mathrm{NAO}_{\mathrm{H}}$ for $15 \%$ and variability $\Delta \mathrm{F}$ for $5.9 \%$ of the variance of the 550 annual temperature in Wrocław (TWr) in the considered period. The trend of TWr values 551 calculated from equation [3] increased and is practically the same $\left(+0.035( \pm 0.003)^{\circ} \mathrm{C}-\mathrm{year}{ }^{-1}\right)$ as 552 in the series of observed values. This suggests that variable $\Delta \mathrm{F}$ introduces only a better fit of the 553 trend (in relation to the real TWr trend) into equation [3], as a manifestation of TWr variability.

554 A review of the graphs of series $\mathrm{TWr}, \mathrm{ShWr}_{04-08}, \mathrm{NAO}_{\mathrm{H}}$ and $\Delta \mathrm{F}$, from which the trends were 555 removed, and their comparison with the course of observed TWr values confirms the above556 mentioned suggestion. Similarly, regression analysis, in which TWr devoid of the trend was the 
557 explained variable, and $\mathrm{ShWr}_{04-08}, \mathrm{NAO}_{\mathrm{H}}$ and $\Delta \mathrm{F}$ were the explanatory variables from which the

558 trend was removed, allowed us to create an equation with only two variables: The $\mathrm{ShWr}_{04-08}$ and

$559 \mathrm{NAO}_{\mathrm{H}}$ jointly explain $\sim 46 \%$ of the variance of the explained variable. The calculation program

560 (progressive stepwise regression) eliminated the trend less variable $\Delta \mathrm{F}$ without as statistically

561 insignificant $(\mathrm{p}=0.939)$.

562

563 Discussion of the results and conclusions

565 The problem of a rapid change of the thermal regime

The obtained results of the analysis show that variability of the three simple independent variables: $\mathrm{ShWr}_{04-08}, \mathrm{NAO}_{\mathrm{H}}$ and $\Delta \mathrm{F}$ explains together $68.5 \%$ of the annual variance of the air

569 temperature in Wrocław in the years 1951-2018. A proportion of the explained variance is high,

570 because without explanation is only $31.5 \%$ of the TWr variability.

571 It is significant, that no discontinuity in the $\Delta \mathrm{F}$ course for the years 1951-2018 does not

572 occur. On the other hand, such discontinuity, less or more distinct, in the similar courses of the 573 two variables: $\mathrm{ShWr}_{04-08}$ and $\mathrm{NAO}_{\mathrm{H}}$ occurs in the years 1987-1989. It explains, in the statistical 574 sense, a radical change of the annual air temperature course in Wrocław. It only from this time 575 (1987-1989) could say, that a progressive warming occurs. However, it is a question: what a 576 climatic process, or a group of these processes is the reason of this warming and why since 1988 ?

577 The reason for the observed warming is a change in the macro-circulation conditions in the 578 Atlantic-Eurasian circular sector, expressed as a change of the so-called "circulation epochs".

579 Circulation epochs are determined based on changes in the structure of macro-types of central 
580 and middle tropospheric circulation (Girs, 1971; Girs and Kondratovich, 1978). Within a given

581 epoch, the structure of the macro-types of the middle-tropospheric circulation $\mathrm{W}, \mathrm{E}$ and $\mathrm{C}$ 582 (according to the classification of Wangengejm-Girs; structure of the macro-types - 'a

583 proportion' between frequency of the W, C, E macrotypes in the examined year. The sum of 584 these macro-types is constant and is equal of number of days in a year) is relatively constant, 585 typical for a longer period: ten years or more. Changes in the structure lead to the transition from 586 one epoch to the next, with a new structure of the macro-types frequency.

587 In the years 1951-2018, circulation epochs changed twice. (Savichev et al., 2015) define the 588 following circulation epochs: until 1965 (1949-1965): The E+C Epoch, from 1966 to 1989: The 589 E Epoch and from 1990 to 2014: The W Epoch (The quoted 2014 year does not indicate, that 590 circulation epoch has closed in that year. It indicates only that (Savichev et al., 2015) made of the 591 series of macrotypes frequency solely to the year 2014). Degirmendžić and Kożuchowski, (2018) 592 distinguish the same epochs in the years 1951-2018, and their limits show small shifts in relation 593 to the limits set by Savichev et al., (2015). According to Degirmendžić and Kożuchowski, (2018) 594 the end of the E+C Epoch falls in 1969, the beginning and the end of the E Epoch respectively in 5951970 and 1991, and the beginning of the W Epoch in 1992. In view of the different methods of 596 defining the boundaries of macro-circulation epochs by the quoted authors and the different 597 moments of the beginning of the analysis, these differences are of little significance.

598 The moment the annual air temperature regime in Wrocław changed and a strong upward 599 trend appeared in a series happened in the years 1987-1989; which is very close to the change of 600 the circulation epoch E to W according to Savichev et al., (2015) (1989/ 1990), and according to 601 the divisions by Degirmendžić and Kożuchowski, (2018) in the years 1991/ 1992.

602 At the same time (1987-1989), a similar change in the annual air temperature regime was 603 taken place at numerous European stations, from the French coast of the Bay of Biscay 
604 (Merignac Aeroport de Bordeaux: $44.8^{\circ} \mathrm{N}, 0.7^{\circ} \mathrm{W}$ ) to the British Isles and the southern

605 Scandinavian. It was also noted all over Germany, Switzerland and other countries of Central

606 Europe as well as in vast areas of the Russia Lowland (Minsk, Moscow) up to Kazan (55. $7^{\circ}$ N,

$\left.60749.2^{\circ} \mathrm{E}\right)$ and Arkhangelsk $\left(64.3^{\circ} \mathrm{N}, 40.3^{\circ} \mathrm{E}\right)$. The change in temperature regime was also

608 manifested at some European high mountain stations in the Alps (Saentis, Zugspitze) and in the

609 Sudetes (Snezka) and the Carpathians (Kasprowy Wierch). This confirms that the revealed

610 change in the annual temperature regime in Wrocław is a manifestation of macro-scale processes,

611 not local processes.

612 The review of the annual anomaly of the attendance of $\mathrm{W}, \mathrm{E}$ and $\mathrm{C}$ macro-types in the years

613 1951-2018 (Fig 9) shows that in 1987 the frequency of all three macro-types of the middle-

614 tropospheric circulation approached the values corresponding to the multi-annual average of the

615 period 1951-2015. After 1988 the frequency of the macro-type W became higher than the long-

616 term norm, the attendance of the macro-type E dropped below the long-term norm, and the

617 frequency of the macro-type $\mathrm{C}$ oscillates around the long-term average.

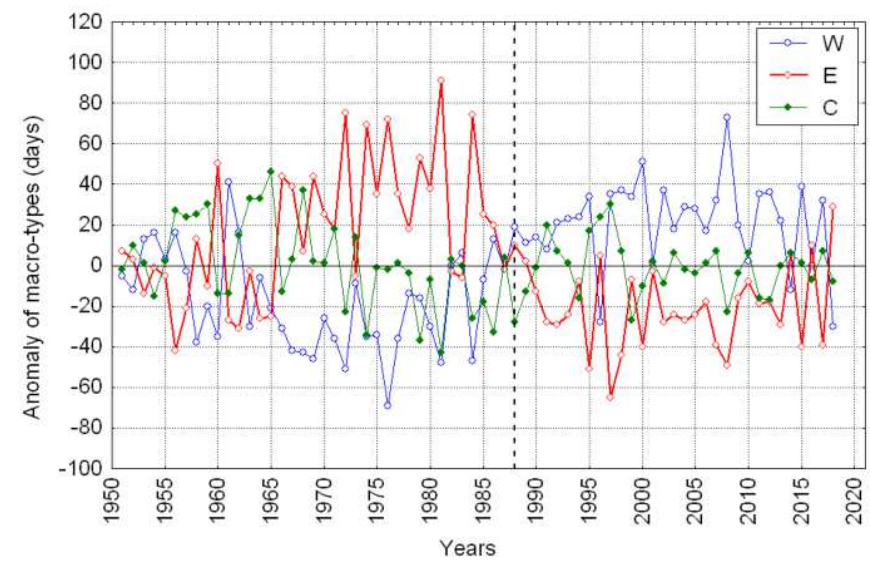

618

619 Fig 9. The course of the anomaly of the annual frequency of $\mathrm{W}, \mathrm{E}$ and $\mathrm{C}$ macro-types of the middle620 tropospheric circulation according to the classification by Wangengejm-Girs. The anomalies calculated 
621 with reference to averages from the period 1951-2015. The vertical dashed line marks the moment of

622 transition of circulation epoch E to circulation epoch W

624 The frequency of macro-type $\mathrm{W}$ which is higher than normal of the in the last circulation 625 epoch, after 1988, results in a change in weather structure in relation to the previous epoch. Each 626 macro-type is associated with the occurrence of a specific synoptic situations in the lower 627 troposphere (e.g. 'circulation types’ by (Fortuniak et al., 2001; Marsz, 2005; Osuchowska-Klein, 628 1991, 1978). Therefore after 1988, macro-type W weather became more common, above the

629 multi-annual average, and at the same time, macro-type E weather types fell below the 630 multiannual average. Since the average values of climatic elements averaged monthly or annually 631 depend directly on the weather structure occurring in a given month or year, the values of several 632 climatic elements depend on the frequency of macro-types. As a result of the cause-effect chain, 633 there are direct correlations between the frequency of $\mathrm{W}$ and $\mathrm{E}$ macro-types and air temperature 634 and sunshine duration, as well as a weaker correlation with annual precipitation totals (PWr 635 variable) in Wrocław (Table 4).

637 Table 4 Values of correlation coefficients and their statistical significance (lower line in each cell) 638 between the annual frequency of $\mathrm{W}, \mathrm{E}$ and $\mathrm{C}$ macro-types of the middle-tropospheric circulation and 639 annual temperature (TWr), annual sunshine duration (ShWr), sunshine duration of the long-day months. $640\left(\mathrm{ShWr}_{\mathrm{r} 04-08}\right)$ and annual precipitation (PWr) in Wrocław (1951-2018). Markings as in Table 1.

\begin{tabular}{|c|c|c|c|c|}
\hline Macro-types & TWr & ShWr & ShWr $_{04-08}$ & PWr \\
\hline \multirow{2}{*}{ W } & $\mathbf{0 , 4 7}$ & $\mathbf{0 , 6 2}$ & $\mathbf{0 , 6 3}$ & $\mathbf{- 0 , 3 1}$ \\
& 0,000 & 0,000 & 0,000 & 0,010 \\
\hline \multirow{2}{*}{ E } & $\mathbf{- 0 , 3 0}$ & $\mathbf{- 0 , 6 0}$ & $\mathbf{- 0 , 5 9}$ & $\mathbf{0 , 3 3}$ \\
& 0,014 & 0,000 & 0,000 & 0,005 \\
\hline
\end{tabular}




\begin{tabular}{|c|c|c|c|c|}
\hline $\mathbf{C}$ & $\mathbf{- 0 , 2 4}$ & 0,09 & 0,04 & $-0,10$ \\
& 0,047 & 0,488 & 0,729 & 0,431 \\
\hline
\end{tabular}

643 Lower frequency of macro-type $\mathrm{E}$ and the simultaneous increase of macro-type W frequency 644 led to an increase in sunshine, also during the 'long day' period, and an increase in the 645 temperature in Wrocław. Since the attendance of macro-type E in 1986-1991 dropped rapidly 646 (Fig. 9), sunshine duration and temperature changed accordingly. Certain influence on the rapid 647 increase in air temperature in Wrocław may also be exerted by a decrease in annual precipitation 648 along with an increase of macro-type $\mathrm{W}$ frequency and a decrease of macro-type $\mathrm{E}$ attendance 649 (Table 4). Smaller annual precipitation and increased solar radiation reduces heat loss for 650 evaporation (latent evaporation heat), which increases the share of sensible heat streams in 651 turbulence exchange, boosting air temperature increase with the same radiation energy supply to 652 the surface of the area.

653 The winter NAO index, which increased in the same period, also generously contributed to 654 air temperature increase (Głogowski et al., 2020). The winter NAO index is highly significantly 655 associated with the macro-type W frequency from January to March $(\mathrm{r}=0.51, \mathrm{p}<<0.001)$ and 656 less negatively with the macro-type $\mathrm{E}$ attendance in the same period $(\mathrm{r}=-0.31, \mathrm{p}=0.011 ; 1951-$ 657 2018). As a result, the change in the frequency of macro-types $\mathrm{W}$ and $\mathrm{E}$ led at the same time to a 658 strong increase in the intensity of western circulation in winter. The values of the winter NAO 659 index increased from year to year (from +0.75 in 1987 and +0.72 in 1988 to +5.08 in 1989 and $660+3.96$ in 1990). A large increase in the frequency of polar air advection caused an increase in 661 temperature in winter, which in turn had a strong influence on the TWr value. The macro-type W 662 frequency prevailed at least until 2017, above its long-term norm, and it caused the strong 663 warming that has been going on since 1989. 
664 Therefore, the mechanism of temperature increase in Wrocław is linked to the increase in

665 winter temperature forced by the increased attendance of the positive phase of NAO and summer

666 temperature, caused in turn by the increase in sunshine duration, can be consistently explained by

667 the change of macro-circulation conditions. Both result from processes functioning within the 668 climate system and have rather little to do with anthropogenic global warming in terms of causes.

670 The role of intra-system climatic processes in shaping air temperature

\section{1 variability in Wroclaw}

673 The regression analysis shows that together, the two independent variables, being a 674 manifestation of the internal dynamics of the climate system, explain about $63 \%$ of the annual 675 variance of the air temperature in Wrocław between 1951-2018. It means that all other factors, 676 that are not included in equation [2], but which influence the formation of the annual temperature 677 variance over, can explain at most $\sim 40 \%$ of its variability. The inclusion of radiative forcing as 678 the third independent variable (equation [3]) explains that the increase in $\mathrm{CO}_{2}$ concentration in 679 the atmosphere, i.e. the process that leads to the AGW, accounts for only $~ 6 \%$ of the annual 680 variance of air temperature. This last value constitutes only about 1/10 of the part of the TWr 681 variance that is explained by the effects of intra-system climatic factors.

682 This indicates that the variability of the annual temperature in Wrocław is mostly shaped by 683 the processes resulting from the internal dynamics of the climate system and these processes play 684 an essential role in the increase in air temperature. Two simple factors - the sunshine duration of 685 the 'long day' months and the 'winter' NAO, explain together slightly more than $60 \%$ of the TWr 686 variance. The growth in sunshine duration after 1988 regulates the increase in air temperature 
687 during the months of the 'long day', i.e. the warm season, the variability of the winter NAO

688 indicator affects the air temperature during the cold season, when for purely natural reasons, the

689 inflow of sunlight to the surface is very limited in moderate latitudes.

690 The increase in the heat resources in the atmosphere that causes the air temperature to rise

691 during the warm season comes from the increased inflow of solar radiation (ShWr04-08) to the

692 ground. This is the simplest possible process leading to an increase in air temperature. The heat

693 causing the temperature rise during the cold season comes from the surface of the North Atlantic

694 from where it was transported to Poland together with air masses by atmospheric circulation

695 (NAO), raising the temperature during the winter months. Heat taken from the surface of the

696 North Atlantic is also solar heat - it comes from short-wave radiation, which was previously

697 absorbed and accumulated in near-surface volumes of ocean waters.

698 In the light of the above, the hypothesis of the dominant role of increasing $\mathrm{CO}_{2}$ concentration

699 in the atmosphere as the main, or the only, cause of the temperature increase observed at present

700 should be carefully addressed. Its share in explaining the annual air temperature variation in

701 Wrocław does not exceed $6 \%$. The role of increasing $\mathrm{CO}_{2}$ concentration, and thus the role of

702 human activity in shaping the currently observed increase in air temperature, seems to be

703 definitely overestimated.

\section{Acknowledgements}

705 The research was funded by the internal recourses of Wroclaw University of Environmental and

706 Life Sciences

\section{Contributions}


The participation of Andrzej A. Marsz includes Conceptualization, Methodology and Formal analysis, Anna Styszyńska includes the Investigation, Visualization, Writing - Original Draft

710 Preparation, Krystyna Bryś includes the Project Administration, Supervision, Writing - Review \&

711 Editing and the participation of Tadeusz Bryś includes Resources, Data Curation, Validation.

\section{Ethics declarations}

\section{Ethics approval}

714 The authors confirm that this article is original research and has not been published or presented

715 previously in any journal or conference in any language (in whole or in part).

\section{Conflict of interest}

717 The authors declare that they have no conflict of interest.

\section{Consent to participate and consent to publish}

719 The authors declare that they have consent to participate and consent to publish.

\section{$721 \quad$ References}

722 1. BACC, T., 2008. Assessment of climate change for the Baltic Sea basin. Springer Science 723 \& Business Media.

724 2. Barry, R.G., Carleton, A.M., 2013. Synoptic and dynamic climatology. Routledge.

725 3. Besharat, F., Dehghan, A.A., Faghih, A.R., 2013. Empirical models for estimating global

726 solar radiation: A review and case study. Renew. Sustain. Energy Rev. 21, 798-821.

727 https://doi.org/https://doi.org/10.1016/j.rser.2012.12.043

728 4. Black, J.N., Bonython, C.W., Prescott, J.A., 1954. Solar radiation and the duration of

729 sunshine. Q. J. R. Meteorol. Soc. 80, 231-235.

$730 \quad$ https://doi.org/https://doi.org/10.1002/qj.49708034411 
5. Brázdil, R., Budíková, M., Auer, I., Böhm, R., Cegnar, T., Faško, P., Lapin, M., GajičČapka, M., Zaninović, K., Koleva, E., Niedźwiedź, T., Ustrnul, Z., Szalai, S., Weber, R.O., 1996. Trends of maximum and minimum daily temperatures in central and southeastern Europe. Int. J. Climatol. 16, 765-782. https://doi.org/https://doi.org/10.1002/(SICI)1097-0088(199607)16:7<765::AIDJOC46>3.0.CO;2-O

6. Bryś, K., Bryś, T., 2010. Reconstruction of the 217-year (1791-2007) Wrocław air temperature and precipitation series. Bull. Geogr. Phys. Geogr. Ser. 3, 121-171. https://doi.org/https://doi.org/10.2478/bgeo-2010-0007

7. Bryś, K., Bryś, T., Głogowski, A., 2019. Long-wave radiation balances of the south-west Poland, in: E3S Web of Conferences. https://doi.org/10.1051/e3sconf/201911600013

8. Bryś, K., Bryś, T., Ojrzyńska, H., Sayegh, M.A., Głogowski, A., 2020. Variability and role of long-wave radiation fluxes in the formation of net radiation and thermal features of grassy and bare soil active surfaces in Wrocław. Sci. Total Environ. 747, 141192. https://doi.org/10.1016/j.scitotenv.2020.141192

9. Büntgen, U., Myglan, V.S., Ljungqvist, F.C., McCormick, M., Di Cosmo, N., Sigl, M., Jungclaus, J., Wagner, S., Krusic, P.J., Esper, J., Kaplan, J.O., de Vaan, M.A.C., Luterbacher, J., Wacker, L., Tegel, W., Kirdyanov, A. V, 2016. Cooling and societal change during the Late Antique Little Ice Age from 536 to around 660 AD. Nat. Geosci. 9, 231-236. https://doi.org/10.1038/ngeo2652

10. Cohen, J., Barlow, M., 2005. The NAO, the AO, and Global Warming: How Closely Related? J. Clim. 18, 4498-4513. https://doi.org/10.1175/JCLI3530.1 the North Atlantic Oscillation*. J. Phys. Oceanogr. 31, 3374-3400. 
12. Czaja, A., Frankignoul, C., 2002. Observed impact of Atlantic SST anomalies on the North Atlantic Oscillation. J. Clim. 15, 606-623.

13. Czaja, A., Robertson, A.W., Huck, T., 2003. The role of Atlantic ocean-atmosphere coupling in affecting North Atlantic Oscillation variability. In-Situ Meteorological and Hydrological Datasets For Environmental Assessment. Sustain. . https://doi.org/10.3390/su12010394

15. Degirmendžić, J., Kożuchowski, K., 2018. Circulation epochs based on the VangengeimGirs large scale patterns (1891-2010).

16. Dimitrieev, A.A., Belyazo, V.A., 2006. Calendar catalogue of atmospheric processes in the Northern Hemisphere circumpolar zone and their characteristics in the period 19492005 (in russian). Cosmos, Planet. Clim. Var. Atmos. Polar Reg. St. Petersbg. Gidrometeoizdat. przykładzie Wrocławia). Wydawn. Uniwersytetu Wrocławskiego. Pr. i Stud. Geogr. 29. Wrocławia-Informator 9-25. 
and Ocean-Atmosphere Interactions*. J. Phys. Oceanogr. 31, 3516-3529. https://doi.org/10.1175/1520-0485(2002)031<3516:GSVAOA>2.0.CO;2

22. Girs, A.A., 1971. Multi-year changes of the atmospheric circulation and long-term hydrometeorological forecasts (in russian). Leningrad, Gidrometeoizdat.

23. Girs, A.A., Kondratovich, K. V, 1978. Methods of long-term weather forecasts (in russian). Leningrad, Gidrometeoizdat.

24. Głogowski, A., Bryś, K., Bryś, T., 2020. Influence of NAO on forming the UTCI index in Kłodzko. Theor. Appl. Climatol. 142, 1555-1567. https://doi.org/10.1007/s00704-020$03340-\mathrm{y}$

25. Hu, F.S., Ito, E., Brown, T.A., Curry, B.B., Engstrom, D.R., 2001. Pronounced climatic variations in Alaska during the last two millennia. Proc. Natl. Acad. Sci. 98, 10552 LP 10556. https://doi.org/10.1073/pnas.181333798

26. Hurrell, J.W., 1995. Decadal trends in the North Atlantic Oscillation: regional temperatures and precipitation. Science (80-. ). 269, 676-679. https://doi.org/10.1126/science.269.5224.676

28. IPCC, 2014. Climate change 2014: synthesis report. Contribution of Working Groups I, II and III to the fifth assessment report of the Intergovernmental Panel on Climate Change. Ipcc. University Press. 
Climate Change.

31. Kopp, G., Krivova, N., Wu, C.J., Lean, J., 2016. The impact of the revised sunspot record on solar irradiance reconstructions. Sol. Phys. 291, 2951-2965.

32. Kożuchowski, K., Żmudzka, E., 2001. The warming in Poland: the range and seasonality of the changes in air temperature in the second half of 20th century. Przegląd Geofiz. 46, 81-90.

33. Kwiatkowski, J., 1975. Zasięg fenów sudeckich i ich wpływ na mezoklimat regionów południowo-zachodniej i środkowej Polski. Przegląd Geogr. 20, 1. 516.

35. Marsz, A.A., 2006. Into some interpretations of the effects of the North Atlantic Oscillation (NAO) activity (in polish). Czas. Geogr. 3, 220-228. Baltic Sea (1854-2005), in: The Polish Climate in the European Context: An Historical Overview. Springer Netherlands, pp. 355-374. https://doi.org/10.1007/978-90-481-31679_16 Aktru Glacier (Central Altai) and changes tree line fluctuations in its basin for a historical period. Лед и снег 56, 103-118.

39. Ojrzyńska, H., 2015. Cyrkulacyjne uwarunkowania przestrzennego rozkładu temperatury powietrza w terenie zróżnicowanym morfologicznie na przykładzie Sudetów. Instytut Geografii i Rozwoju Regionalnego Uniwersytetu Wrocławskiego. 
40. Oreopoulos, L., Mlawer, E., Delamere, J., Shippert, T., Cole, J., Fomin, B., Iacono, M.,

828 Jin, Z., Li, J., Manners, J., 2012. The continual intercomparison of radiation codes:

$829 \quad$ Results from phase I. J. Geophys. Res. Atmos. 117.

$830 \quad$ https://doi.org/https://doi.org/10.1029/2011JD016821

831 41. Osuchowska-Klein, B., 1991. Katalog typów cyrkulacji atmosferycznej:(1976-1990).

832 IMGW.

833 42. Osuchowska-Klein, B., 1978. Catalogue of the atmospheric circulation types (in polish).

$834 \quad$ Wydawn. komunikacji i lacznosci.

835 43. Philipona, R., Behrens, K., Ruckstuhl, C., 2009. How declining aerosols and rising 836 greenhouse gases forced rapid warming in Europe since the 1980s. Geophys. Res. Lett.

837 36. https://doi.org/10.1029/2008GL036350

838 44. Savichev, A.I., Mironicheva, N.P., Tsepelev, V.Y., 2015. Atmospheric circulation

839 characteristics of the Northern Hemisphere Atlantic-Eurasian sector for last decade (in

840 russian). Uchenye Zap. RGGMU 120-131.

841 45. Semenov, V.A., Latif, M., Jungclaus, J.H., Park, W., 2008. Is the observed NAO

842 variability during the instrumental record unusual? Geophys. Res. Lett. 35.

843 https://doi.org/https://doi.org/10.1029/2008GL033273

844 46. Szymanowski, M., 2005. Interactions between thermal advection in frontal zones and the

845 urban heat island of Wrocław, Poland. Theor. Appl. Climatol. 82, 207-224.

$846 \quad$ https://doi.org/10.1007/s00704-005-0135-2

847 47. Szymanowski, M., 2004. Miejska wyspa ciepła we Wrocławiu. Wyd. Uniwersytetu

$848 \quad$ Wrocławskiego.

849 48. Urban, G., Migała, K., Pawliczek, P., 2018. Sunshine duration and its variability in the 850 main ridge of the Karkonosze Mountains in relation to with atmospheric circulation. 
Theor. Appl. Climatol. 131, 1173-1189. https://doi.org/10.1007/s00704-017-2035-7

49. Ustrnul, Z., 2006. Spatial differentiation of air temperature in Poland using circulation

853 types and GIS. Int. J. Climatol. 26, 1529-1546.

854 https://doi.org/https://doi.org/10.1002/joc.1393

855 50. van Loon, H., Rogers, J.C., 1978. The Seesaw in Winter Temperatures between

856 Greenland and Northern Europe. Part I: General Description. Mon. Weather Rev. 106,

857 296-310. https://doi.org/10.1175/1520-0493(1978)106<0296:TSIWTB>2.0.CO;2

858 51. Wójcik, R., Miętus, M., 2014. Some features of long-term variability in air temperature in 859 Poland (1951-2010). Przegląd Geogr. 86, 339-364.

860 